\title{
La muerte de Alfonso XII y la configuración de la práctica política de la Restauración *
}

\author{
M. ángeles Lario González
}

\section{INTRODUCCIÓN}

Para entender el derrumbamiento del régimen político que vio la luz tras la Restauración borbónica en 1874, derrumbamiento que se produjo bajo la monarquía de Alfonso XIII, es imprescindible analizar en profundidad no sólo la teoría constitucional elaborada al efecto en 1876 , sino, a la vez, la práctica política que creó un determinado estilo de relación entre las instituciones, que es el que nos puede explicar la causa de la fluidez en el intercambio político y la buena imagen que en general ofrecen las dos situaciones monárquicas anteriores a la monarquía citada: la de Alfonso XII y la Regencia de M. ${ }^{a}$ Cristina, frente a la controversia histórica que generó el último reinado.

Para profundizar en esta práctica política, en estas normas no escritas que prevalecieron en la relación entre los partidos durante la Regencia, nada mejor que estudiar aquellos momentos en que todas las instituciones convergen en sus competencias, esto es, las crisis políticas.

En cada crisis que significa cambio de partido en el gobierno, o, en su caso, pudo haberlo significado, entran en juego, $1 .^{\circ}$ Las prerrogativas de la Corona, que según el artículo 54.9 de la Constitución «nombra y separa libremente a los ministros» (en teoría esta prerrogativa se pondría en funcionamiento también en cada reestructuración de los gobiernos, pero en la práctica queda transferida al Presidente del Consejo de Minis-

* Este artículo forma parte de mi tesis doctoral, en período de elaboración, titulada La Corona y las relaciones institucionales durante la restauración de 1875 a través de las crisis políticas U.N.E.D., dirigida por D. Javier Tusell. 
tros). 2. ${ }^{\circ}$ Las de las Cortes, ya que en un sistema en que desde 1837 se acepta de hecho que el gobierno ha de ser representativo, rompiendo con la tradición gaditana de separación absoluta de poderes, aquél ha de contar con una mayoría suficiente en las Cortes que le permita, al menos, cumplir con los artículos 85 («todos los años presentará el gobierno a las Cortes el presupuesto general de gastos del Estado para el año siguiente...») complementado con el 3 («Nadie está obligado a pagar contribución que no esté votada por las Cortes..."), y artículo 88 ("Las Cortes fijarán todos los años, a propuesta del Rey, la fuerza militar permanente de mar y tierra"); de hecho, además los gobiernos han de tener su confianza, al igual que la de la Corona, según la teoría doctrinaria de la soberanía compartida (en el encabezamiento de la Constitución de 1876 se lee: «Don Alfonso XIII... en unión y de acuerdo con las Cortes... hemos venido en decretar y sancionar..."), y ambas confianzas han de garantizar gobiernos en sintonía con la opinión pública. $Y 3 .^{\circ}$ Las del propio Gobierno, que aunque como institución, al igual que en otros países liberales, no aparece todavía regulado en la letra constitucional (aunque se menciona su existencia unas veces como Consejo de Ministros (arts. 59 y 70) y otras como gobierno (arts. 85 y 89); a pesar de ello, deciamos, su poder radica en el endose de la responsabilidad de los actos del monarca, en la necesidad de que todo mandato del Rey, para llevarse a efecto tenga que estar refrendado por un ministro (art. 49); de tal forma que éstos son los únicos responsables de todo acto regio, y quien tiene la responsabilidad tiene la capacidad última de decidir; es decir, un gobierno, y sobre todo el partido llamado a gobernar, puede negarse a aceptar el poder cuando el Rey se lo ofrece, de hecho debe hacerlo si considera que la decisión del Monarca no es acertada, puesto que sólo el jefe político que acepta el poder es el único responsable de esa aceptación, y por tanto del acto regio que provocó un cambio de gobierno.

Es decir, que en cada crisis política confluyen los poderes de las tres instituciones fundamentales: Corona, Cortes y Gobierno; y el análisis de las mismas significa el de la relación entre estos poderes.

Acercándonos un poco más a la práctica política, hay que señalar que si bien el gobierno es el nexo de unión entre la Corona y las Cortes, y la vía por la que discurren todas las relaciones que entre ambas instituciones se hayan de establecer; el partido político es el nexo de unión entre las Cortes y el Gobierno, de tal manera que un control eficaz del partido político por parte de su jefe, implica un control eficaz de las Cortes, siempre creadas ad hoc por cada gobierno, dada la generalizada corrupción en el sistema electoral (sobre todo desde la Ley Orgánica de Ayuntamientos de 1840 por la que se puso freno al poderoso poder municipal a través de la designación gubernativa de alcaldes acabando con los 
ayuntamientos electivos y favoreciendo el control de las elecciones por parte del gobierno). Con esto es fácil entender que el partido en el gobierno, y sobre todo su presidente tenía todos los hilos para el control político: por un lado se responsabiliza y ejerce de hecho el poder de la Corona, a la que debía aconsejar aceptando o no sus mandatos; y por otro disponía de las mayorías necesarias en las Cortes.

Llegados a este punto hay que destacar la importancia del papel ejercido por el partido político, ya que le da la fuerza al Gobierno en las Cortes, siempre que se mantenga cohesionado y disciplinado bajo su jefe, de la misma forma que ante la Corona, en las mismas circunstancias, ya que garantiza una armónica relación entre las dos instituciones soberanas a la par que evita la posibilidad de que el monarca tenga que elegir entre una serie de líderes importantes; peligro siempre presente dado el sistema de clientelismo por el que se forman los partidos, en los que determinados políticos destacados aportan numerosas mesnadas al mismo y pueden aspirar a formar grupos políticos diferenciados; sólo pueden ser controlados por el veto tajante del resto de los grupos y sobre todo del partido de la oposición, que al negarle beligerancia condena a la monarquía, en el caso de que ésta mostrara preferencia por los disidentes, a gobernar con un solo grupo, ni siquiera partido, con todos los demás enfrente de ambos. Se hacía evidente, entonces, la necesidad de una normativa, no necesariamente escrita, que regulara el comportamiento político de aquéllos, sobre todo a la hora de aceptar o abandonar el poder, dado que dependían exclusivamente de la Corona; normas que les hiciera árbitros de su propio poder, al no buscarlo en la Corona sino en sus propios mecanismos de intercambio.

Este control que los partidos políticos pudieron ejercer sobre sí mismos y por tanto sobre el poder de la Corona, pudo conseguirse cuando los dos que dominaban el panorama político decidieron crear esas normas para producir el recambio político, ante la expectativa de una Regencia en manos de una mujer de la que desconocían casi todo, y desde luego sus capacidades para discernir las conveniencias políticas e incluso su conocimiento del sistema establecido en un país que no era el suyo y al que había llegado hacía seis años, sin que se le hubiera conocido ningún interés por los asuntos políticos. El sentido de las conversaciones entre los dos líderes monárquicos tras la muerte de Alfonso XII, no pudo ser sino el de controlar las crisis políticas o lo que es lo mismo, controlar el poder de la Corona para nombrar libremente a los ministros, según lo demuestran los sucesos posteriores. No hay que entender por tanto el pacto monárquico como un intento poco confesable de repartirse el pastel del poder, tanto como la decisión de evitar a la monarquía, en sus momentos más débiles, cualquier posible responsabilidad que la debilitara 
aún más; pero a la vez consiguiendo en aquel crítico momento, lo que quizás Cánovas nunca se atrevió a esperar de los liberales y en concreto de Sagasta, esto es, la culminación de todo el sistema político que partiendo de las grandes atribuciones concedidas a la Corona en cosoberanía con las Cortes, significara en la práctica un férreo control por parte del Gobierno y su presidente de toda la trayectoria política que salvaguardara al país de cualquier nuevo sobresalto, después de la sucesión de tantos que fueron salpicando la historia del siglo que estaba transcurriendo y al que se quería aportar al menos estabilidad política.

Esto que se consiguió en 1885, fue precisamente de lo que careció el reinado de Alfonso XIII. Este pacto entre los partidos para controlar el poder regio no se reprodujo una vez desaparecidos Cánovas y Sagasta, primero, probablemente frenado por el ambiente creado tras el $98 \mathrm{y} \mathrm{el}$ afán de caminar hacia una nueva política que respondiera a los nuevos problemas, y segundo, por el intento equivocado de algunos eminentes políticos, como Maura, de frenar al Rey personalmente, como enfrentamiento personal, sin acudir a la práctica eficaz del control a través de los partidos políticos, o en su caso a través de unas Cortes verdaderamente representativas. La crisis de 1909 puso en evidencia el definitivo final del antiguo pacto para el predominio de los partidos y sus jefes, ahora divididos y enfrentados, no solamente en su vida interna sino además en sus relaciones con el oponente. Por la primera circunstancia, la división interna, se perdía la posibilidad de control sobre las Cortes; por la segunda, el público y decidido enfrentamiento entre los líderes, el no otorgamiento de beligerancia, el "Maura no", se perdía el control sobre la Corona, que quedaba de esta suerte avocada a ser juez y parte de todo el proceso político; se la dejaba al descubierto con todo su poder y por tanto con toda su responsabilidad. Los partidos políticos que no eran capaces de controlar Cortes ni Corona, se lanzaron a la lucha a los pies del Trono, institución que quedó como la única con la fuerza suficiente para evitar, momentáneamente al menos, el colapso político que significaban los partidos políticos sin fuerza y las Cortes sin representación y por tanto incapaces de promover recambios políticos eficaces. En el reinado de Alfonso XIII, al contrario que en los anteriores, y más evidentemente en la Regencia, se esperaba todo del monarca, incluso la autolimitación de su propio poder, cuando no había ningún otro que se le pudiera oponer, toda vez que se prescindió de cualquier reforma electoral encaminada a hacer más representativas, y por tanto poderosas, a las Cortes, a la vez que los partidos políticos fracasaron en la tarea que Silvela les encomendara de dirigir la vida política. 


\section{LA SITUACIÓN POLITICA ANTES DE LA MUERTE DEL REY}

En la discusión de la crisis que llevó al poder de nuevo al partido conservador (17 de enero de 1884) habían arreciado las críticas a las costumbres políticas que iban asentándose. Parecía que había llegado el momento de la revisión y la crítica a la práctica establecida; ésta se basaba en el predominio del Gobierno, en particular de su presidente, sobre las demás instituciones políticas. El control sobre las Cortes resultaba evidente, puesto que las controlaba en su nacimiento con el encasillado desde el Ministerio de la Gobernación y el caciquismo a nivel local. La vida de las mismas, posteriormente, quedaba controlada de igual modo asegurando la unidad de los partidos basada en la jefatura indiscutible de los mismos; y estableciendo como norma, que el jefe del partido habría de ser el jefe del Gobierno cuando aquél fuera llamado a gobernar. Por fin, el final de la vida de las Cortes dependía de la capacidad del Gobierno, a su vez, de controlar a la Corona. En este punto se había logrado mucho; facilitado en primer lugar por la convicción de Cánovas de que lo más eficaz y seguro era que aquél fuera el primer controlador de la vida política; y en segundo lugar, por la natural predisposición del monarca restaurado de acatar las decisiones de aquellos que hicieron posible el retorno de la monarquía borbónica, y de él mismo que la personificaba; y la de respetar sobre todo la dirección política de quien estaba encargado de construir la necesaria legalidad para perpetuar la nueva situación. A Cánovas se le había otorgado desde el exilio poderes para actuar, encaminados a conseguir esta Restauración y dejando libre el camino para la configuración política del régimen. Ahora la monarquía ya estaba restaurada, pero faltaba lo más importante, asentarla definitivamente dentro del marco político creado por la Constitución de 1876, hacer convivir el poder de las Cortes con el de la Corona, unos partidos con otros, y que todos los políticos - cuantos más mejor-aceptaran un cierto estilo de relación entre los poderes, que hiciera más fluido y controlable el proceso político. Este hecho influía de modo esencial en las relaciones del Rey con el Presidente del Gobierno.

Sin embargo la situación de lucha entre los partidos por conseguir el poder, sobre todo tras 1880 , cuando se le otorga beligerancia al partido fusionista de Sagasta -las crisis de 1879 tuvieron como importante consecuencia la separación de Martínez Campos y otros eminentes generales restauracionistas, del partido conservador y su agregación al partido de Sagasta-, concedía al Rey un cierto campo de actuación, puesto que tenía que elegir libremente entre dos e incluso más posibles tipos de política, y $\sin$ un control parlamentario eficaz; de hecho hasta 1885 se sucedieron las políticas conservadora, liberal de Sagasta y la izquierda 
de Serrano, aunque bajo la tutela de Posada Herrera y sin decreto de disolución - para cuya obtención le faltó confianza en el gobierno a algún miembro del mismo, a Moret de un modo evidente--.

Esta posibilidad de actuación, a su vez, movilizaba a los liberales, en estos momentos todavía muy críticos, y les hacía concebir posibilidades de cambio e incluso reformas de las costumbres políticas todavía no firmemente asentadas; se llegó a pedir la intervención del Rey para sanear la vida política, para hacer cumplir a sus gobiernos la sinceridad en las elecciones. Se juzgaba precaria la situación de la propia institución monárquica, que tenía que actuar sin brújula que la orientara en el camino de la opinión pública, dependiendo su actuación solamente del criterio político de los partidos y expuesta consecuentemente a ser colocada en el medio de su previsible lucha de intereses. Por el mismo camino se podía sospechar que se produciría un progresivo alejamiento de la realidad del país, quedando encerrada en la telaraña política tejida por esos mismos partidos. Todo eso se preveía y se criticaba ya en 1884; en las siguientes Cortes liberales, el afín Ramos Calderón dirá que a la muerte de Alfonso XII las Cortes habian perdido mucho de su prestigio y la monarquía se había debilitado, pero en este año de 1886 la situación era ya distinta y la postura del partido liberal en esta monarquia había sido trazada a la muerte del Rey '. Todavía en 1884 se podía pensar en una sana evolución del régimen, sin embargo la prematura muerte del monarca, paralizó todo intento de reforma y se elevó lo hasta entonces conseguido y criticado a categoría de máximo bien a defender frente a los que pretendieran aprovechar la coyuntura para cambiar radicalmente el estado de cosas. Las noticias que llegan a Palacio y a los jefes de los partidos políticos son alarmantes, especialmente desde 1884 cuando se habla de la unión de republicanos e internacionalistas, a los que habría que añadir los «aventureros" del carlismo (Tristany, Berriz...), e incluso el Grande Oriente, donde se percibe la salida de monárquicos y la entrada de muchos republicanos ${ }^{2}$; el propio Azcárate dijo en el Parlamento que la revolución ya tenía el camino hecho y que se habria producido de haber continuado Cánovas en el poder, situación que el propio jefe conservador supo apreciar; pero esta misma situación, al producirse la muerte del Rey,

1 Diario de Sesiones del Congreso (DSC), leg. 1886, t. I, discurso de Ramos Calderón, 22 de junio de 1886 .

2 Archivo de Palacio (AP), informe de MORET, de marzo de 1884; Cajón 23/7. Cartas de PÉrez DE BrAY a Guillermo Morphy, secretario particular del Rey, y al propio monarca, a lo largo de 1885; Cajón 26/7. Informes del embajador en Londres, MARQUÉS DE CASA-LAIGLESIA también al Conde de Morphy, a lo largo de 1885, sobre las actividades de Ruiz Zorrilla; Cajón 26/1.A. 
hizo que la Restauración tomara su tono (sic), su modo de ser, del partido conservador, y no del partido liberal ${ }^{3}$.

Esta grieta en el edificio todavía en construcción, hizo reforzar las bases sobre las que se venía levantando. De esta manera el pacto entre los políticos reafirmó de una vez el poder del Gobierno y su Presidente frente a las Cortes y el Rey. En la Regencia de doña M. ${ }^{a}$ Cristina de HabsburgoLorena, la Corona deberá tener bien delimitado su campo de acción, encargándose los jefes de los dos partidos turnantes de dirigir el devenir político y la sucesión de los gobiernos, de un modo más evidente de lo que había sido antes - sobre todo después de 1880, o incluso 1879- y desde luego, de lo que será después.

El citado pacto político hay que entenderlo, pues, en este contexto: frente al arraigado concepto de que significó un descarado reparto del poder, de lo que se trataba era de controlar el proceso político por si las nuevas manos que sustentaban la Corona no acertaran a desempeñar su papel adecuadamente; el único modo de controlar este proceso era sustituyendo la lucha por el poder, que daba preeminencia a las regias prerrogativas, por la armonía y "buena intención" de los jefes políticos que habrían de conocer y aceptar los momentos en que debían permanecer en la oposición y en el gobierno. Tampoco hay que creer, tal y como se produjeron las conversaciones, según veremos más adelante, que se hubiera establecido este sistema de un modo genérico y permanente, sino que más bien fue ideado para la ocasión grave en que se encontraba la vida política: Cánovas se encontraba dispuesto, no sólo a traspasar el poder al partido liberal, sino además aceptar su política sin una campaña de oposición; claro que para ello, a su vez, Sagasta parece seguro que estuvo dispuesto a no llevar a cabo, y menos en aquellos momentos, una política radical, como se podía suponer tras la alianza con los demócratas en 1884 y la aceptación de la llamada "Ley de Garantías".

\section{LA SITUACIÓN DE LOS PARTIDOS POLITICOS ANTES DE LA CRISIS}

El partido liberal, tras su salida del poder definitivamente el 17 de enero de 1884 (tras las experiencias liberal de Sagasta y la prácticamente nonnata izquierdista, liderada por Posada Herrera, que había llegado con el propósito de unir las fracciones liberales sin conseguirlo, cuyo fracaso abrió el camino a los conservadores) entendió que la unidad le era im-

${ }^{3}$ DSC cit., discurso de AzCÁRATE de 23 de junio. 
prescindible si quería justificar su futura petición del poder; en esta tarea fueron ayudados por los conservadores ${ }^{4}$ que sin duda entendieron tras la crisis del gobierno de Posada, que no había partido liberal posible fuera de Sagasta; y por la propia división de la izquierda liberal, que hizo que el 4 de junio de 1884 quedara formado el gran partido liberal, aceptando Sagasta una fórmula que venía a justificar la incorporación del grupo de la izquierda y el acatamiento de su jefatura por parte de personajes tan relevantes como Moret o Montero Ríos; esta fórmula planteaba la necesidad de una Ley de Garantías "para cumplir según el criterio liberal, lo que se prescribe en los artículos 14,27,77 y otros de la Constitución del Estado", y que debería contener entre otros artículos el $5 .^{\circ}$, por el cual se procedería a una reforma constitucional por Cortes especialmente convocadas y elegidas "y en virtud de un acuerdo del poder legislativo, en que se señale el artículo o artículos que hayan de derogarse o reformarse... la reforma constitucional comenzará a regir a los quince días de su promulgación», también se pedía el sufragio universal, el jurado, manteniendo la representación de la soberanía nacional en las Cortes con el Rey ${ }^{5}$. No hay duda de que sobre todo ese artículo $5 .^{\circ}$ de la pretendida Ley de Garantías no resultaba nada tranquilizadora para los conservadores en general ni para Cánovas en particular, pues dejaba abierta la vía a una incierta reforma constitucional como programa liberal, que además no se sabía qué amplitud podría tener sobre todo en cuanto a los poderes fundamentales. No se podía negar que el último trayecto conservador del reinado de Alfonso XII estaba preñado de inquietantes movimientos políticos en el campo liberal y republicano. A la izquierda de Sagasta sólo quedaba el General López Domínguez, continuador del grupo de Serrano, ya retirado de la vida política y que moriria un día antes que el propio monarca; en este grupo se mantenían Linares Rivas, L. F. Aguilar, Becerra, Acuña, León y Llerena, García Torres, Marqués de Oviedo, España, Montilla y Oliver, y los generales Bermúdez Reina, González Iscar, Armiñán, Burgos y Marqués de Ahumada. Este grupo se mantuvo incluso después de la muerte del Rey puesto que reunidos el 1 de diciembre decidieron no variar programa ni procedimientos.

El nuevo partido así coaligado, se pondrá frente decididamente de lo que representa la unión del partido conservador con la Unión Católica de Pidal en el poder. En este contexto se alían con los republicanos, de los que ahora se sienten más cerca, para presentarse a las elecciones mu-

\footnotetext{
“ Varela Ortega, José, Los amigos politicos. Partidos, elecciones y caciquismo en la Restauración (1875-1900), Madrid, Alianza Editorial, 1977, págs. 191-192.

"La Época 28 de noviembre de 1885. "El programa liberal".
} 
nicipales de abril de 1885; y a pesar de que Romero Robledo dirige el Ministerio de la Gobernación, el gobierno conservador es derrotado en las principales ciudades. Sobre esta inusitada victoria, el embajador en Londres envía significativos recortes de periódicos ingleses que aluden a la inesperada situación creada en España, siendo significativa la posición de The Times que si bien entiende que la consecuencia lógica es la dimisión del gobierno, dado el modo en que se produjo la crisis, es decir, la alianza de liberales y republicanos, les parece más recomendable mantenerlo de momento. Sin embargo alude a la posibilidad de que este acontecimiento signifique el principio del fin de los abusos en las elecciones. Por su parte Standard destaca la poco grata situación del Rey que debería elegir entre la unión que estaba gobernando, o la que se presenta en la oposición, ambas representativas más de una radicalización de posturas que de una armonía política. Daily News finalmente alude a la demostración que hicieron los republicanos de mantenerse dentro de los límites legales siempre que fueran tratados imparcialmente, por lo que de prosperar pasaría la responsabilidad de la estabilidad del sistema a los poderes establecidos y no a las fuerzas revolucionarias; también señala que tras estas elecciones quedaría demostrado que incluso con el derecho de voto restringido, los liberales unidos a los republicanos estaban en mayoria en España (sic) ${ }^{6}$.

Así se presentaba el partido liberal bien avanzado el año de 1885, en medio de una crisis ya crónica dentro del gobierno conservador que parecía no encontrar ocasión apropiada para salir del poder a pesar de su precaria situación, como veremos.

La situación del partido conservador, y más concretamente del gobierno conservador, antes de la muerte del Rey, no era precisamente de estabilidad y optimismo; la presencia del ultramontano Pidal en Instrucción Pública y sus opiniones en cuanto a la libertad religiosa y de cátedra ${ }^{7}$

${ }^{6} A P$, recortes de diarios ingleses enviados por el MARQuÉS de CASA-LAIGLESIA al secretario del Rey. Son del 11 de mayo de 1885. Por orden de cita: Spain. The Spanish Ministry, y Political Parties in Spain. Cajón 26/1.A. cit. Según EsPIna CAPO, Antonio, Notas del viaje de mi vida (18811890), págs. 134 ss, la coalición ganó en Madrid, Barcelona, Gerona, Lérida, Zaragoza, Huesca, Teruel, Valencia, Castellón, Murcia, Córdoba, Almería, Jaén, Huelva, Badajoz, Salamanca, Zamora, Valladolid, Burgos, Logroño, Ávila, Santander, Segovia, Palencia, Ciudad Real, Bilbao, Oviedo, Orense, Pontevedra, La Coruña y Palma de Mallorca: treinta provincias, con minorías muy respetables en las demás.

7 Vid. Camponar y Fornielles, Marta, “Menéndez Pelayo en el gran debate parlamentario de 1884-1885", Boletín de la Biblioteca de Menéndez Pelayo. Santander 1986. De la misma autora: La cuestión religiosa en la Restauración. Historia de los Heterodoxos... Santander, Sociedad Menéndez Pelayo, 1984. 
había proporcionado al gabinete una vida accidentada, desde el mismo año de 1884, recién estrenado el gobierno conservador: la defensa que hizo Pidal del poder temporal del Papa frente al reconocimiento de la unidad italiana, en junio en el Congreso, llegó a provocar un conflicto diplomático y obligó al propio Cánovas a intervenir en favor de la citada unidad. Hay que tener en cuenta la utilización que los liberales hacen de esta dicotomía que existe en el gobierno; pero no sólo los liberales, sino todos aquellos que se encuentran a la izquierda de la mayoría, temen la influencia que la Unión Católica pueda ejercer en la evolución del partido conservador; Castelar en el Congreso trata de desprestigiar esta unión de Cánovas y Pidal, mientras Sagasta pide a este último que si no está de acuerdo con la libertad religiosa dimita. En noviembre surge un enfrentamiento en la universidad, iniciado por estudiantes íntegros, amparados por una carta pastoral del Obispo de Ávila en contestación al discurso de apertura del curso universitario, que había llevado a cabo el krausista Morayta; aquella pastoral va seguida de una circular del Vicario de Toledo que se lee en las iglesias y tras esto se produce la manifestación de los estudiantes; primero los íntegros, luego los liberales, provocando una escalada de acontecimientos que termina con el allanamiento de la Universidad Central por parte de la fuerza pública.

En el Congreso amanece el año 1885 con acalorados e incluso violentos debates; incluso se habla del fin de la reconciliación que los conservadores habian propuesto al iniciarse la Restauración. El enfrentamiento de Pidal al anterior gobierno liberal, personificado en su ministro de Fomento, Albareda, parecía poner en peligro la necesaria convivencia pacífica entre los sucesivos gobiernos; e incluso podía radicalizar excesivamente las posiciones liberales ante el tema religioso. El 14 de febrero llega a decir Castelar: "En verdad os digo que la política de los neo católicos derribó antes al trono de Israel Il y ahora derribará al trono de Alfonso XIl» ${ }^{8}$. Sagasta por su parte habla de un clima de guerra civil entre católicos y liberales. Desde luego no parecía el mejor clima para preservar la vida de un gobierno, dividido además en su seno por el enfrentamiento entre Silvela y Romero Robledo, puesto en evidencia en el Congreso cuando ambos discuten acerca de la crisis de julio de 1885 por la que el segundo salió del Ministerio de la Gobernación, siendo sustituido por Villaverde (le acompañó en su salida Antequera, siendo sustituido en Marina por De la Pezuela y Lobo); aunque el 15 de julio Romero alegó cuestiones personales para abandonar el gobierno, en esta discusión queda claro

${ }^{8}$ Cit. en Campomar Fornielles, Menéndez Pelayo..., cit., pág. 305. 
que la crisis venía aplazándose desde la derrota del gobierno en las elecciones municipales de abril, que en aquella ocasión no se le aceptó la dimisión porque implicaba, además de reconocer la derrota, reconocer a su vez la desunión del gobierno pues que Romero afirmó "que no se había creído suficientemente apoyado por algunos de sus compañeros y amigos", refiriéndose evidentemente a Silvela, el que más se oponía a su conducta política, y planteando así una crisis eminentemente política que precisaría para ser resuelta una crisis general, poco adecuada en aquellos momentos. Confirma Silvela que él habría salido con Romero del gobierno en el mismo instante, con lo que no deja lugar a duda de la situación planteada. Si acaso alguien no se había enterado de estas discrepancias, Silvela las explica en profundidad, pues que entra a analizar el papel que deben desempeñar los partidos políticos frente a la concepción de su oponente y otros que no cita; en definitiva le acusa de anteponer cuestiones particulares a los deberes ante los poderes públicos, adelantándose a lo que tras el pacto entre los partidos, se entenderá que debe ser el papel de estos últimos; no dejando a los altos poderes del Estado el regular la hora en que han de abandonar el poder, sino que ellos mismos tienen el deber de una alta imparcialidad para juzgar sus propias fuerzas y la oportunidad de su gobernación. Planteó así como doctrina, lo que el pacto intentará llevar a la práctica tras la muerte de Alfonso $\mathrm{XII}^{9}$.

A esta situación mantenida durante toda la vida de este gobierno, hay que sumarle problemas añadidos que afectaban a su crédito público. Este es el caso del viaje que hizo el monarca de incógnito a Aranjuez, para visitar a los afectados por el cólera en aquella ciudad, a las puertas de Madrid, y que era el coletazo final de una discrepancia con su jefe de gobierno por la oportunidad o no de visitar las provincias afectadas por este mal. La decisión del Rey de actuar a espaldas del gobierno, fue interpretada por muchos, y sobre todo por los que aspiraban a heredar el poder, como la muestra fehaciente de la falta de confianza regia que padecía el Gabinete; cuestión de suma importancia en un régimen que establece las dos confianzas - del Rey y las Cortes-como base de su funcionamiento. El hecho es que el 2 de julio del Rey, con sólo la presencia de un ayuda de cámara, salió antes de las siete de la mañana del Palacio hacia la estación del Mediodía donde su acompañante adquirió dos billetes ordinarios hacia Aranjuez; cuando llegó a su destino recorrió la población y los hospitales de apestados; a las once de la mañana, sin embargo, alertados tanto por el jefe de la estación que lo había reco-

'DSC, leg. 1885-86, tomo único, discursos de Romero Robledo y de Francisco Silvela, el 4 de enero de 1886 . 
nocido, como por las notas dejadas por el propio monarca a la Reina y al Presidente del Consejo, partieron en la misma dirección en un tren especial, el Ministro de la Guerra, General Quesada, y el Capitán General de Castilla la Nueva, General Pavía. Cuando volvió, más o menos a las cinco de la tarde, le esperaba una nutrida representación política: el Senado y el Congreso habían suspendido sus reuniones para poder ir a recibirle, el gobierno en pleno se encontraba en la estación, y la oposición, formados en un gran grupo, le aclamó con fuerza. De nuevo el embajador inglés envía recortes de periódicos al Palacio para dar a conocer la interpretación que se hace de este acontecimiento que pudo haber traído importantes consecuencias políticas; no hay que olvidar que pocos días antes el gobierno había hecho cuestión de gabinete el pretendido viaje regio a Murcia, por lo que el Rey había transigido en ese punto. La postura general es aplaudir el acto del Rey, mencionando el precedente del Rey Humberto de Italia el año anterior, y asociándolo incluso al Príncipe de Gales por su nivel de caballerosidad y valentía, demostrando que desea ser sinceramente el padre de su pueblo (sic); el Morning Post recalca el éxito de lo que entiende que fue un impulso del Rey, porque venció lo que consideran que era una vida de corte artificial, con una fuerte etiqueta mantenida desde Carlos I. The Times, alude a los posibles e inmediatos efectos políticos que podía acarrear esta actitud del Rey, a la que el gobierno intentó quitar importancia alegando que el viaje lo hizo en su faceta de militar para visitar los regimientos de tropas allí destacados, argumento poco creíble por la ausencia del ministro de la Guerra, que sólo en un segundo momento se incorporó a la visita, de la que sólo tuvo conocimiento una vez iniciada ${ }^{10}$. Este fue un momento más en que la oposición pudo pedir fundada y airadamente su llegada al poder, basándose en la condición sine qua non que había establecido el gobierno poco tiempo atrás para continuar en el poder. Sin embargo ahora, el mismo Ministerio que se había opuesto en esa forma a las pretensiones del Rey de viajar a Murcia con idéntico objetivo al que guió su viaje a Aranjuez, se encontró aplaudiendo este viaje que había causado tan favorable y viva impresión en la opinión pública. De este modo doblegándose evitó la crisis una vez más.

Casi dos meses después, la ocupación alemana de la isla de Yap, en las Carolinas, le vino a proporcionar otro revés político al ministerio de Cánovas: el 4 de septiembre se produjo un asalto a la legación alemana en Madrid, teniendo como consecuencia inmediata la reunión de los li-

${ }^{10} A P$, recortes de diarios ingleses del 3 de julio de 1885. Cajón 26/1.A. cit. 
berales en casa de Sagasta. Por otra parte los conflictos entre Alemania y España, parece que se aprovecharon por los revolucionarios que cifraban sus esperanzas en el rompimiento de relaciones que habrian de facilitar el advenimiento de la República, a pesar de que a su vez Zorrilla dudaba, una vez que fueron sucediéndose los acontecimientos, que la actitud de Alemania fuera tan comtemporizadora en caso de que no fueran los monárquicos los que ocuparan el poder; hay nombres propios en estos informes que se envían sobre los trabajos revolucionarios, por ejemplo Juan Anglada, Tomás Carretero, Santos La Hoz, Brigdier Villa-Campa ${ }^{11}$. Desde este momento la crisis política no dejó de ser actualidad, siendo precisamente los liberales quienes estaban decididamente a favor del rompimiento de relaciones y de la declaración de guerra.

\section{LA CRISIS CRÓNICA}

Como consecuencia de estos acontecimientos, decíamos, en la noche del 4 de septiembre se reunieron los prohombres liberales en casa de Sagasta; a esta reunión acudieron Martos, Martínez Campos, Jovellar, Venancio González, Marqués de la Vega de Armijo y Montejo y Robledo. Se dice que por casualidad estuvo presente el General Salamanca, hecho que no podia pasar desapercibido por los monárquicos puesto que entre los pasquines que aparecieron por Madrid a finales de agosto, habia uno que decía: «Españoles, el Rey nos engaña iviva el General Salamanca!”, en relación con el conflicto con Alemania. Al lado de éste, otros llamaban a una manifestación en contra de aquella nación, que entre otras cosas decia que el gobierno reaccionario estaba dispuesto a derramar sangre liberal. Sobre este mismo general, el embajador en Londres citado, dice que junto con López Domínguez, según informes que llegan a Zorrilla, están dispuestos a echar al Rey y que además Salamanca «dará muchos trastornos. con acuerdo o sin acuerdo de Zorrilla y de López Domínguez ${ }^{12}$. De hecho los informes del 23 de septiembre desde aquella legación indican la inminencia de un atentado contra el monarca en la primera ocasión que se presentara, apoyado por el mismo General Salamanca, conspiración que el propio emperador alemán conoce y comunica al Marqués de Casa Laiglesia ${ }^{13}$.

"AP, carta a Pérez de Bray desde Barcelona, 19 de septiembre de 1885. Cajón 26/7. Según los informes del MARQUÉS DE CASA-LAIGLESIA, Zorrilla cree que este momento le es favorable, dice contar con mil cuatrocientos veinticuatro oficiales y gran número de sargentos, con seis o siete individuos por regimiento, también con empleados de Correos y Telégrafos y otros; 10 y 18 de septiembre; cajón 26/1.A.

${ }^{12} A P$, cajón 26 cit., informe del 18 de septiembre.

${ }^{13}$ AP, carta al Marqués del Pazo de LA Merced del 13 de octubre. Idem. 
Así pues, fuera o no casualidad, la presencia de este general y el optimismo de los conspiradores en este clima de conflicto exterior, daría más significación si cabe a la resolución a la que llegaron los liberales la misma noche de los disturbios; las conclusiones a que llegaron aunque no se formularon en forma de acuerdos, se pueden sintetizar en los siguientes puntos: 1. Alemania declaró la guerra a España al ocupar la isla de Yap; $2 .^{\circ}$ España debe emprender consecuentemente las acciones oportunas: expedición desde las islas Filipinas, retirada de pasaportes al embajador alemán y retirada del embajador destacado en Berlín; $3 .^{\circ}$ el gobierno conservador por errores y desgracias, no está capacitado para utilizar todos los recursos posibles, aunque el partido liberal siempre estaría dispuesto a ayudarle en estas acciones; $4 .^{\circ}$ el partido liberal está decidido y capacitado para asumir el poder y llevar a cabo todas las medidas necesarias en este asunto ${ }^{14}$. Es decir, tras los acontecimientos de principios de septiembre, el partido liberal hizo una petición formal del poder, que tenía todos los visos de ser eficaz a no muy largo plazo, a pesar de los inconvenientes, o por ellos mismos, que producía su conflictivo acercamiento y confusión de intereses con los republicanos. En estas conclusiones no se olvidaron de hablar al Rey "confiando", dicen, en que se inspirara en supremos intereses "y se actuara todos juntos sin diferencia de partido", en un evidente intento de hablar en el idioma institucional, el que hablan los que llaman a las puertas del gobierno.

Estas conclusiones que no firmaron los seguidores de López Domínguez por rivalidades de iniciativa, según nos cuenta el artículo de La Época citado, coinciden sin embargo con su propio pensamiento, y en carta que este diario recoge del General a Rute, le dice que cdebemos aceptar serenos la lucha". De esta forma todo el campo liberal estaba de acuerdo con su enfrentamiento a la inactividad del gobierno conservador. $\mathrm{Ni}$ siquiera la pretendida utilización del grupo de López Domínguez por parte de Romero Robledo para doblegar a los liberales ${ }^{15}$ parecía producir efectos positivos para el decaído gobierno, posiblemente porque en esta época ya el ex-ministro de Gobernación tiene tanto interés en vencer a los enemigos que se encuentran en su propio partido, como a los de la oposición.

Sin embargo La Época se apoya en las diferencias de estrategia entre el partido liberal y la izquierda, para mantener que el poder debe seguir

${ }^{14}$ El Imparcial, 5 de septiembre y 18 de noviembre de 1885. La Época, 7 de noviembre: "Una opinión del General López Dominguez".

is Varela Ortega, J., Los amigos políticos..., cit., pág. 193. 
en manos conservadoras, cuando ya los primeros venían reclamando la crisis; el 10 de noviembre lo dicen claramente: "Con razón pensamos que el único enemigo que tienen los liberales anida en su seno y que la única dificultad que ofrecen a la regia prerrogativa y a las victorias del Parlamento, está en su naturaleza rebelde a todo lo que es orden, disciplina, unión y patriotismo»; a la vez los informes que se reciben sobre Ruiz Zorrilla, aluden al deseo que los revolucionarios tienen de que lleguen al poder los liberales para poder actuar con más libertad y acabar de completar su organización; de hecho Zorrilla dice que «la entrada de los liberales es indispensable a la realización de nuestras esperanzas» ${ }^{16}$. La postura de los liberales es la de negarse en redondo a que las Cortes fueran abiertas de nuevo antes de hacer crisis el gobierno amenazando incluso con retirarse de ellas, practicando una vez más el retraimiento. Esta actitud se agudizó cuando ya las negociaciones con Alemania se daban por prácticamente terminadas, tras el arbitrio dictado por el Papa León XIII el 22 de octubre, a petición de Cánovas y aceptado por la parte alemana; ahora la interinidad del gobierno no tenía razón de ser, según la oposición; interinidad que mantenía en suspenso toda actuación de largo alcance, como el nombramiento de senadores vitalicios, que debían serlo por la Corona, y cuya propuesta por el Gobierno y aceptación por el Rey, implica una amplia confianza regia, mostrándose una vez más la carencia de ella, o la inseguridad de poseerla del propio Gabinete.

El Imparcial, que ahora se podía considerar bien cercano al nuevo partido liberal, desde la incorporación del núcleo izquierdista, hacía este balance de la situación, el 18 de este mismo mes de noviembre: «El aislamiento cuando no la hostilidad, en que la política internacional de los conservadores los ha colocado para con casi toda Europa, la Hacienda devorada por un déficit aterrador y próxima a perecer en los escollos de la deuda flotante; la escisión que germina en el seno de las huestes ministeriales; la impopularidad creciente del Gabinete, su flaqueza ante todo lo que tiene alguna fuerza y sus desafueros y arbitrariedades con todo lo débil, todas las razones, en fin, de orden interior y de índole internacional, son otros tantos fundamentos para el fallo de desahucio de una situación que vino fuera de tiempo y sólo en virtud de divisiones que han desaparecido, porque todos los grandes elementos de aquella izquierda que riñó con el partido liberal, los Martos, los Montero Ríos, los Moret y lo más granado de la democracia, han llegado a un completo acuerdo y disciplina con la antigua mayoría del señor Sagasta. Andan, es

${ }^{16} A P$, copia de una carta de Zorilla, enviada por el embajador en Londres desde BadenBaden, al Conde de Morphy, 10 de octubre. Cajón 26/1.A. cit. 
cierto, los señores López Domínguez y Becerra en agrupación aparte con sus importantes amigos; pero dispuestos - según han declarado- a apoyar en todas las soluciones a cuantos gobiernos que se inspiren en la libertad.» Creían también que el Gabinete, en el mismo sentido de lo dicho anteriormente, dudaba de la confianza regia y evitaba llevar al Rey cuestiones que significaran una existencia a largo plazo del Gobierno, pero creen que éste no tiene fuerza ni resolución de afianzar su poder, faltándole a la vez el valor para facilitar el cambio, uforjándose asi una situación tan inestable que no parece que subsisten por propia fuerza, sino por falta de ocasión o de punto concreto en que pudiera fundarse la crisis" ${ }^{17}$.

Ante esta situación, el único argumento que encuentran los que apoyan la continuación del gobierno es el que les otorga la teoría constitucional, el respeto al Parlamento, la necesidad de no provocar crisis fuera de él; sabiendo que al contar con una importante mayoria, por esa vía nunca iba a salir del poder. Con ello lo que hacen es poner sobre las cuerdas de la argumentación a la oposición, que consecuentemente denuncia la farsa del sistema sostenido sobre bases teóricas constitucionales que son continua y premeditadamente violadas; se tacha a las Cortes de ficción inútil y se les niega todo prestigio y toda fuerza, como hace el órgano fusionista La Gaceta Universal; o como otro diario, La Izquierda Dinástica, que ahay que protestar o envilecerse ${ }^{18}$. En cualquier caso la excusa oficial que presentan los liberales para oponerse a la apertura de Cortes es que la discusión parlamentaria, en exclusivo beneficio del gobierno, que buscaba amparo en su mayoría, perjudicaría a la Corona, pues sería aprovechada por los republicanos la situación de división y debilidad del partido gobernante; entonces la suprema ética política era defender la monarquía frente a todo ataque exterior, eso les proporcionaba unas fronteras políticas dentro de las cuales se encontraban aquellos en los que el Rey podía y debía confiar, para su propio bien; era la forma más contundente de pedir el poder.

\footnotetext{
17 El Imparcial, 6 de noviembre de 1885: “Todo en el aire". La Época, en "Ecos del día", daba noticia de la petición de crisis en El Imparcial y en El Globo, de Castelar, para en los días siguientes agudizarse esta petición, con la suma lógica de La Iberia, de Sagasta; El Correo, también fusionista, La lzquierda Dinástica, de Montero Ríos. El diario conservador se duele sobre todo de la postura de El Imparcial, "al que creíamos menos dispuesto a los lugares comunes y a las frases gordas" (18 de noviembre); y pasa a poner en duda, como en un último intento de defensa con el ataque, la inevitabilidad de que Sagasta herede el poder; Ilamando a López Domínguez a la lucha por el poder, que daría una viva imagen de división en las huestes liberales.

${ }^{18}$ Recogido por La Época, 22 de noviembre: "La crisis y el Parlamento"
} 
En la segunda mitad de noviembre, la preocupante enfermedad del Rey, la actividad revolucionaria de Zorrilla, su alianza con Castelar según publica El Correo, fusionista, el mayor movimiento de los carlistas, e incluso la preocupación por renovadas aspiraciones de Montpensier ${ }^{19}$ y el temor acerca de la actitud de la Reina Madre, hace que se considere esta situación como muy delicada; se teme incluso por un retroceso en la actitud alemana que, según parece, actuó influida por la defensa del trono español al que consideraban en peligro si se llevaba más adelante el conflicto, en cuyo concepto no fue ajeno el propio Rey español y las buenas relaciones mantenidas con el emperador. El embajador inglés que viaja a principios de octubre a Alemania para asistir a la fiesta de la emperatriz teme, efectivamente, que si esta nación considerara inútil su postura, ante la delicada salud regia y la conflictiva situación política, diera marcha atrás en su positiva actitud ${ }^{20}$.

Ante esta situación, los conservadores, efectivamente, no sabían cómo y cuándo dejar el poder; hay que pensar que Cánovas no sabía qué era peor, mantenerse o abrir el camino a los liberales y quién sabe si a los republicanos; sobre todo existía la incertidumbre ante la salud del Rey, que el año anterior ya había superado otra fuerte crisis en el mal que padecía. En esta espera se produjo su muerte el 25 de noviembre, tras un decisivo agravamiento que movilizó a los jefes políticos.

\section{LA MUERTE DEL REY DECIDE LA CRISIS. LA INTELIGENCIA MONÁRQUICA}

La circular de Moret, como ministro de Estado del nuevo gobierno liberal surgido tras la crisis, a los representantes de España en el extranjero, explica la causa por las que la muerte del Rey no trajo sucesos revolucionarios ${ }^{21}$; primero, dice, por la debilidad de carlistas y zorrillistas (contradiciendo su propio informe de marzo de 1884 en donde alude a la gravedad de las circunstancias por la buena situación de los conspiradores republicanos, ver nota 2); y segundo, por «la conducta seguida por el señor Cánovas del Castillo al ponerse en contacto con el señor Sagasta y pedirle su cooperación (aunque fue Martínez Campos quien

19 AP, carta de Ricardo López a M. Ladevese, enviada por el embajador inglés. Cajón 26 cit.

${ }^{20}$ La carta citada al Marqués del Pazo de la Merced, de 13 de octubre. Carta al Conde de Morphy del 5 de este mismo mes, donde alude y pide informes sobre la intervención del Rey en el conflicto con Alemania, que, dice, conocen mejor que él los alemanes, "sin duda por los informes de Solms".

${ }^{21}$ AP, Circular de MORET de 5 de diciembre de 1885. Cajón 13/3. 
inició los encuentros entre los dos políticos según veremos) para salvar la monarquía constitucional sin condición alguna, cooperación ofrecida inmediatamente y con el mayor entusiasmo. Porque así como el temor de que se dividieran las opiniones de los monárquicos sembraba la alarma, asi la inteligencia de todos los partidos monárquicos y su aceptación de la legalidad constitucional sin dudas y sin vacilaciones produjo en el acto salvadora reacción. La opinión que cogida al improviso hubiera podido quizá extraviarse, tomó inmediatamente dirección fija y siguió el derrotero patriótico trazado por los jefes de los partidos. El ejército en el cual no se ha manifestado el menor asomo de indisciplina, contribuyó poderosamente a esta dirección de la opinión, porque todos los generales y oficiales que tienen alguna influencia, manifestaron instintiva, pero calurosamente en todas las partes que, a pesar de cuanto se había dicho su única aspiración era la de mantener la legalidad». Todavía habia un tercer factor en este «milagro", éste era la propia Reina viuda, con la que no se contaba para atajar la crisis, pues hasta entonces no había destacado y menos políticamente, además era extranjera y mujer, dato que para Cánovas no dejaba de tener importancia ${ }^{22}$. No dejó de asombrar positivamente la actitud de la Regente a la que Moret alaba con multitud de términos: temple de carácter, abnegación, delicadeza constitucional, virtud, sencillez, dignidad como Reina, "su conducta después como soberana aceptando el consejo del señor Cánovas y llamando al partido más liberal de la monarquía para confiar así sus hijas a la lealtad del pueblo español; la delicadeza constitucional con que ha procedido en la cuestión del juramento (según veremos más adelante), prestándolo con arreglo a la opinión de los jefes de los partidos por ella solicitada, su deseo manifestado desde el primer momento de convocar las Cortes para prestar ante ellas juramento y el expuesto al Presidente del Consejo de hacer algún acto de clemencia. Así tanto la opinión pública como la de los hombres capaces de formarla, se fijó en ella y principié a ver que el camino de la legalidad iniciado al pie del lecho de muerte del rey Alfonso XII, hay una fuerza y un elemento de extraordinaria importancia y cuya existencia no se sospechaba".

Respecto al único punto dudoso que podía representar la actitud de algunos militares y civiles agrupados en torno al General López Domínguez (el 1 de diciembre se habían reunido y decidido no variar programa ni procedimiento, según queda dicho), al decir de Moret «lejos de repre-

\footnotetext{
22 Fernández Almagro, Melchor, Cánovas. Su vida y su política. Ed. Tebas, pág. 355, 2.* ed., donde nos refiere cómo en El Solitario y su Tiempo, Cánovas expresa su sospecha de que quizá los pronunciamientos sean inevitables cuando el trono lo ocupa una hembra.
} 
sentar hostilidad a la legalidad ni aun al gobierno, éste tiene razones suficientes para esperar su conformidad, si no su identificación con los propósitos de todos los monárquicos".

La cooperación que establecieron Cánovas y Sagasta para salvar la monarquía constitucional "sin condición alguna", lo que se dio en llamar el Pacto del Pardo, si bien ni fue en El Pardo ni se firmó ningún pacto, iba a significar un nuevo estilo de Restauración, una nueva práctica política. Rojo Arias contestando al Marqués de Molíns que había dicho que la minoría conservadora y el gobierno estaban en una tregua, decía que "eso tiene que ser un pacto porque sino sería la negación de los partidos políticos", acusando al partido liberal por aceptarlo, sabiendo por haberlo dicho el mismo Molíns, que cuando se llevaran a las Cortes los proyectos inspirados en el nuevo programa liberal, los conservadores se opondrían ${ }^{23}$, es decir, que sí existía condición para los liberales, y esta no podía ser otra que posponer en cualquier caso cualquier proyecto de reformas.

La nueva práctica política se asentaba en lo que se había conseguido hasta entonces, pero con el gran avance de un acuerdo entre los partidos gubernamentales, a la par que un reconocimiento mutuo, por el que se iban a acabar las dudas establecidas y fomentadas en el partido liberal sobre su jefatura; ahora no había lugar para "coqueteos" con las fuerzas ajenas al sistema, es decir, se había llegado por fin al asentamiento del régimen que había querido Cánovas y que parecía escapársele por la lucha política establecida en el reinado de Alfonso XII, al que podríamos denominar, época de construcción política, con el grado de imprevisión que ello acarrea; época que el propio monarca con su temprana muerte contribuyó a cerrar, pasando a un período de estabilización por efecto del miedo y la autodefensa frente a los enemigos externos. Si en 1884, a raíz de la vuelta del partido conservador al gobierno, los liberales parecían dispuestos a exigir reformas en las prácticas que se iban estableciendo, a finales de 1885, con la muerte del Rey, queda parado este proceso, que podría haber conducido a la Restauración por caminos diferentes, y se asume con convicción una vida política encaminada a mantener la monarquía de 1876, dirigida y controlada por los partidos políticos desde unas Cortes creadas al efecto; un ejemplo está en el citado discurso de Francisco Silvela, en el que explica lo que debe ser un partido político, cómo ellos mismos deben regular su estancia en el poder, sin recurrir a la Corona, elevándose como árbitros de la política (ver nota 9). De hecho

${ }^{23}$ Diario de Sesiones del Senado (DSS), leg. 1886, t. l. Discursos del Marqués de Molíns. de 26 de mayo de 1886, y de Rojo AaIAs, del 27 del mismo mes. 
la necesidad de pactar con Sagasta dejándole el poder, la vio clara Cánovas, desde un gobierno en crisis crónica, tanto por su propia situación interna como por el clima político creado desde el citado año de 1884: las continuadas críticas de los liberales, su decisión de jugar a la baza republicana, la inquietud política, en fin, no era lo que necesitaba precisamente la nueva situación, en la que cualquier alteración era mala, máxime si partía de órganos monárquicos. Lo primero que urgía era darle salida a la misma y asegurarse el apoyo del partido cada vez más fuerte de Sagasta; era esto sin duda más importante que la propia disidencia surgida dentro de su partido por parte de Romero Robledo que no veía las cosas de igual modo, que no era partidario de haber pasado el poder a los liberales y que, sobre todo, se enfrentaba con el estilo político de Silvela.

No es hasta el día 24 cuando la prensa habla explícitamente de la gravedad de la enfermedad del Rey; el mismo diario El Imparcial en su temprana edición del día 25 , cuando todavía no podían saber la muerte del monarca, cerraba filas en torno a la monarquía constitucional, viendo el peligro supremo en el carlismo, del que se podía temer una guerra, frente a las insurrecciones que podían provocar "los demás partidos". Es en este día 24, que precede a la muerte del monarca, cuando Martínez Campos, que había ido a El Pardo a hablar con la Reina, le dijo que «estimaba necesario que se reclamara para su defensa el concurso del partido liberal. Tras lo que aquélla decidió citar a Sagasta, que acudió a El Pardo a las cuatro y media de esa tarde. En esta conversación Sagasta se mostró dispuesto a defender la legalidad constitucional y ratificó su adhesión al trono. Esta actitud de Sagasta, además no era particular, sino que representaba a su partido, ya que antes de esta entrevista con la Reina se había reunido con Martos, Alonso Martínez, Jovellar, Camacho, González, Moret y Vega de Armijo, habiendo llegado unánimemente al acuerdo de defender el trono, con particulares y encendidas declaraciones de Martos. Tras la entrevista con la futura Regente, se volvieron a reunir los liberales, a los que se sumó por haber sido invitado el Conde de Xiquena, ratificándose en su acuerdo anterior, y conviniendo los medios por los que se podrían vencer las posibles dificultades.

Esa tarde del 24 fue cuando todos pudieron hacerse una idea certera de lo que podía suceder, tras el grave ataque que padeció el Rey el día 23 y que se comunicó al día siguiente. En el mismo Palacio no se supo nada hasta que el propio Capitán General de Madrid, Pavía, se lo comunicó, casi a la par que el Jefe Superior de Palacio, que llegó desde El Pardo. El General Martínez Campos había recibido notificación del suceso por parte de Cánovas y del cuarto militar del Rey, que además fue quien reclamó su presencia, a causa de la cual se había entrevistado con 
la Reina ${ }^{24}$. En los círculos políticos ya se comentaba favorablemente los buenos propósitos que se atribuían a los jefes de los dos partidos dinásticos, antes de que se produjera la reunión definitiva de éstos.

Según nos informa El Imparcial, hacía días que se hablaba de la posible inteligencia monárquica, y parece que las negociaciones estaban ya entabladas; ya el 22 por la noche había recibido el General Martínez Campos noticias de la gravedad en el estado de salud del Rey, por medio de Cánovas, y le había anticipado que por su parte y cualquiera que fuera el puesto del partido conservador, estaría al lado del que defendiera la legalidad constitucional; posteriormente el general había celebrado dos conferencias con el mismo Cánovas, una con Sagasta y con los generales Jovellar, Concha y Quesada. Estos trabajos tuvieron continuación el citado día 24, cuando se tuvo conocimiento de la aguda crisis por la que estaba pasando el Rey; Martínez Campos que, según nos cuenta La Época, realizó numerosas visitas a la Presidencia, fue quien comunicó a Cánovas el acuerdo de los liberales, conviniéndose en esta entrevista que se debían reunir los dos jefes, quedando fijada para las once y media de esa noche la histórica entrevista entre Cánovas y Sagasta.

De esta entrevista dijo $E /$ Imparcial al día siguiente que "la inteligencia fue completa y absoluta" y que «lo único a que prestaron atento cuidado los dos jefes fue a convenir la manera de que la legalidad constitucional no esté ni un solo minuto huérfana de gobierno y autoridad"; es decir, que el objetivo no fue, como luego se interpretó frecuentemente, el reparto burdo del poder, sino la defensa de la legalidad constitucional del 76; lo que sucedió es que la defensa de esta legalidad implicaba el acuerdo entre los partidos para alternarse en el poder con la menor implicación posible del monarca, máxime en los primeros momentos que se desconocía el talante y las posibilidades políticas de la Regente. La política prudente que se consideraba necesaria para perpetuar la Restauración borbónica, exigía suplantar en la medida de lo posible los poderes regios, cuya orientación y cuya capacidad desconocian. De todas formas el acuerdo, que fue previo a la muerte del Rey, se hizo "para cualquiera de las contingencias que la salud del Rey ofrezca», es decir, incluso en el caso, bien improbable a esas alturas, de que recobrara la salud. Esta era sin duda una declaración necesaria, pero evidentemente el acuerdo venía a

\footnotetext{
24 La Época, sin embargo, da la versión de que fue la propia Reina Madre, la que le escribió al general después de la recaída del 23 , pero sin indicarle este empeoramiento, sólo notificándole el deseo del Rey de verle; 25 de noviembre: «El día de ayer». Sin embargo no se volvió a insistir en esta versión. Vid. también El Imparcial, Idem: "Martínez Campos y Sagasta en EI Pardo". En general en ambos, los días 24 y 25
} 
cubrir una futura Regencia, o quizás una larga convalecencia de Alfonso XII, que le imposibilitara seguir cotidianamente la vida política. En esta reunión quedó también establecido que Cánovas declinaría sus poderes en cuanto pudiera hacerlo ante la Corona ${ }^{25}$. Este diario refleja la confianza que produce este acuerdo entre los monárquicos de conseguir la fuerza necesaria para defender la legalidad existente. Se dijo que también López Domínguez ofreció su apoyo a cualquier gobierno liberal que defendiera las instituciones, con lo que parecía definitivamente que la situación era susceptible de ser controlada por los partidos monárquicos.

Pocas horas después de este acuerdo, Alfonso XII falleció en El Pardo, atendido por su primer médico de Cámara, doctor Laureano García Camisón, que había sido nombrado el 2 de enero de ese mismo año (dimitió el 3 de enero siguiente), a causa de sucesivos ataques de disnea, según se informó ${ }^{26}$.

Tras su muerte se dijo, entre otras cosas favorables, que había roto "el antiguo molde de los obstáculos tradicionales", pues decidió "llamar por personalísima iniciativa a los hombres que militando en el campo de la revolución tenia por bandera de libertad y la democracia» ${ }^{27}$.

\section{EL PLANTEAMIENTO DE LA CRISIS}

Ya vimos que la crisis estaba pendiente bastante tiempo antes, y que parecía faltarle tanto al gobierno como al Rey la circunstancia propicia para plantearla; si antes de su muerte muchos la proclamaban y la creian inminente, después de que ésta sucediera, se dijo, tanto que el Rey quería promover el cambio político antes de emprender cualquier viaje, como que la que ya era Regente creía firmemente necesario el cambio de gobierno tras los sucesos del 4 de septiembre; incluso que el propio Cánovas pensaba promoverla en base a las disidencias internas de su partido, para, además, sentar de ese modo precedente en cuanto a la necesaria unión del partido en el gobierno. Según El Mercantil Valenciano, fítica".

${ }^{25}$ El Imparcial, 25 de noviembre de 1885: «La inteligencia monárquica» y «La situación po-

${ }^{26}$ Alfonso XII falleció a los veintiocho años, le faltaban tres días para cumplirlos. Había nacido el 28 de noviembre de 1857; comenzó a reinar el 30 de diciembre de 1874, cuando contaba diecisiete años recién cumplidos. Falleció el 25 de noviembre de 1885.

${ }^{27}$ El Imparcial, 26 de noviembre, "la muerte del Rey Alfonso". Añaden que "no pecamos jamás de aduladores en los dias de triunfo. No asistimos nunca a las solemnidades de sus alegrías; mucho tiempo retraídos permanecimos lejos del campo de los vencedores... después lo apoyamos como emblema de paz». 
"el Rey... había llegado ya también a persuadirse de la necesidad del cambio, y el señor Sagasta tenía pleno conocimiento de lo resuelto que estaba don Alfonso a hacer la crisis. Lo único que faltaba era la ocasión, porque decía el Rey que a un Ministerio no se le despide como a un criado, y necesitaba un asunto político de trascendencia para fundar el cambio. A falta de otro punto más oportuno, porque el señor Cánovas rehuía las cuestiones de confianza, esperando una ocasión favorable para salir airoso del Ministerio, se aconsejó al Rey que tomara por motivo para la crisis el decreto de convocatoria, sin embargo el Rey observó que dicho decreto era el cumplimiento de un precepto constitucional y de ahí las dificultades que oponía para rehusar la firma. Esta especie de gestiones diplomáticas iban con mucha lentitud y sufrian grandes aplazamientos, (por) la enfermedad del Rey" ${ }^{28}$. Lo primero que se desprende, si todo lo relatado en este artículo fuera exacto, es lo bien aprendida que tendría el Rey fallecido la lección constitucional, tanto por los conceptos vertidos, como porque, de hecho, no se produjo crisis mientras vivió, a pesar de que su necesidad venía siendo aclamada hacía ya mucho tiempo y para cuyo planteamiento Cánovas no encontraba acomodo.

Lo cierto es que en la propia muerte del monarca se encontró, sin pretenderlo evidentemente, la circunstancia, aunque azarosa en potencia y complicada, para dar a la luz la crisis que se venía enquistando en el cuerpo político. Así al primer indicio del posible desenlace comenzaron las conversaciones entre las partes, y no había transcurrido media hora de la muerte cuando ya se intentó solucionarla; y es que, si el fallecimiento del Rey era suficientemente preocupante por sí solo, el que se produjera en medio de una crisis política sin solucionar, sin siquiera haber sido planteada, con el partido aspirante en pie de guerra, dejaba al partido conservador en el poder y a su jefe, como promotor de la Restauración, en una posición tan delicada y a la propia situación política en una posición tan incierta, que sólo desandando el camino de enfrentamiento con los liberales, se podía superar. El acierto de Cánovas y Sagasta fue, precisamente, actuar adecuadamente en el momento oportuno. Ambos y Martínez Campos como mediador, tuvieron todo el mérito de hacer pasar al pais pacíficamente de una monarquía todavía en construcción, a una Regencia en aquellos momentos incierta, pues no se fijó el heredero hasta el nacimiento del hijo que $M .{ }^{\text {a }}$ Cristina estaba esperando, el 17 de mayo siguiente, seis meses después, por si fuera varón, como sucedió, y cuya preferencia en la línea de sucesión habría hecho anular los títulos que precipidatamente

${ }^{28}$ Artículo reproducido por El Imparcial el 2 de diciembre, “¿Cómo vino la crisis?" Vid. también en el mismo diario el 26 de noviembre, "El día de ayer». 
se le hubieran concedido a la primogénita de Alfonso XII. Martínez Campos, a quien Cánovas previsiblemente quiso alejar de los centros del poder en 1884 , al ofrecerle la Capitanía General de Filipinas, que el primero rechazó ${ }^{29}$, fue buscado por el jefe conservador cuando la salud del Rey parecía no tener retorno, para conseguir el acuerdo entre los monárquicos; si es que no partió del general una buena dosis de iniciativa para conseguir ese mismo objetivo, una vez que le fue comunicado por Cánovas el empeoramiento del monarca.

Así pues, a la muerte del Rey todo se precipitó; Cánovas tuvo prisa en solucionar el problema del cambio de Ministerio, y se presentó a la Reina sin darle tiempo siquiera a verter las primeras lágrimas por la pérdida que sufrió. Y ello a pesar de las órdenes que aquélla habia dado de que nadie entrara en la cámara mortuoria; para lograrlo tuvo que utilizar su autoridad de Jefe de gobierno ante la servidumbre de Palacio, algo que no pudo parecer bien a la Regente, que le recibió en el umbral de la puerta y se negó a solucionar en aquellos momentos cualquier asunto político, ignorando la dimisión que le presentaba. Por ello, Cánovas comisionó a Martínez Campos, por si podía lograr lo que él no había conseguido; pero el General, más respetuoso con la situación y el dolor de la Reina, no se atrevió a plantearle cuestión alguna, aunque fue ya por la tarde (la muerte se produjo a las ocho y cuarenta y cinco de la mañana). Así pues, el gobierno de Cánovas se autodenominó interino, y pasó a solucionar el tema de la Regencia, haciendo constar que ésta recaía en la Reina viuda, que pasaba a tener toda la autoridad del Rey según los artículos 67 y 72 de la Constitución, y en cuyo nombre se publicarían los actos del gobierno. Se ocupó también de la otra cuestión primordial: el orden público; respecto a lo cual prevaleció el parecer del Capitán General de Castilla la Nueva, General Pavía, quien creyó conveniente proclamar el estado de sitio antes de dar cuenta oficial en La Gaceta del fallecimiento de Alfonso XII; se dispuso que las fuerzas de la guarnición permanecieran en los cuarteles; fueron reforzados con guardia civil de infantería y caballería los retenes de la Presidencia, Gobernación, Legación alemana y otros edificios públicos. Para EI Pardo salieron un regimiento de caballería, otro de infantería, una sección de la guardia civil y parte de la fuerza de alabarderos que quedaba en el cuartel de Madrid ${ }^{30}$.

Por su parte el partido liberal, en ese día, tras una reunión con los exministros, se dispuso a aceptar el poder si la Reina los llamaba, con la

${ }^{29}$ Archivo de Canovas (AC). Carta de Martínez Campos, 1884.

${ }^{30}$ El Imparcial, 25 de noviembre, «Precauciones adoptadas". 
idea de reunir en un gobierno los jefes de todas las agrupaciones liberales, incluso contando con López Domínguez. Este general, por su lado, reunió en su casa a un nutrido grupo, entre civiles y militares, y decidieron no aceptar responsabilidades ajenas, es decir, no entrar en gobiernos de otros grupos que no representaran los principios de la izquierda, a la que consideraban capaz de solucionar los problemas planteados en aquellos momentos; se había manifestado, sin embargo, dispuestos a apoyar a un gobierno liberal desde fuera ${ }^{31}$.

Las dimisiones definitivas se produjeron al día siguiente, 26 de noviembre, a pesar del deseo de la Reina de aplazar la cuestión política mientras estuviera insepulto el cuerpo del Rey. Se produjo una entrevista entre el Presidente y la Regente alrededor de las tres de la tarde, que duró casi una hora, y tras la cual quedó resuelto que no debía demorarse más la solución de este problema, mandándose aviso a Sagasta para que acudiera al Palacio de EI Pardo. En este caso ya las dimisiones iban por escrito, y se basaron en el fin de la confianza regia que disfrutaba el gobierno, al morir aquél que se la había otorgado: “Señora: el fallecimiento nunca bastante llorado de S. M. el Rey, ha hecho expirar el mandato que tenía conferido su real confianza al actual Ministerio. Por otra parte, el Ministro Presidente que suscribe, abriga la profunda convicción de que a un nuevo reinado como el que comenzó ayer, le convienen ministros nuevos también, con quienes pueda realizarse la política que $V$. M. en su alta sabiduría considere más provechosa para la Nación. Por uno y otro fundado motivo suplica reverentemente a $V$. $M$. que se digne admitirle la dismisión de su cargo, rogando al cielo que derrame todos sus dones sobre el sucesor legítimo de don Alfonso XII, sobre V. M., como Regente del Reino y Reina Gobernadora, sobre toda la actual dinastía y la afligida España» ${ }^{32}$.

Sobre esta conversación de Cánovas y la Reina, El Imparcial da una versión que niega $L a E ́ p o c a$, y que en definitiva no puede ser confirmada, entre otras cosas porque de este tipo de acontecimientos sólo se puede tener conocimiento por versiones, o de los interesados o de los «bien informados"; nada cambian las cosas sin embargo, ya que el resultado final fue la llamada de Sagasta y la formación del gobierno liberal, que los conservadores, excepto Romero Robledo, aceptaron. La versión de El Imparcial, en todo caso, destacaba el deseo de $M .{ }^{a}$ Cristina de inaugurar

${ }^{31}$ La Época, 26 de noviembre, "En casa del señor López Dominguez". El Imparcial, Idem., "El General López Domínguez". Vid. también "Las entrevistas con la Reina", en este mismo ejemplar.

${ }_{32}$ Citado por La Época, el 26 de noviembre, pág. 3, “La crisis». La Gaceta, 28 de noviembre. 
su Regencia con "la política más liberal y expansiva que sea defendida por los partidos monárquicos liberales" ${ }^{33}$.

A pesar de ser llamado Sagasta aproximadamente a las cinco de la tarde, éste no tuvo noticia del requerimiento hasta por la noche ${ }^{34}$ en que ya sólo telefoneó a El Pardo y se pospuso su entrevista y la presentación del gobierno para el día siguiente, 27 de noviembre, una vez acabadas las ceremonias fúnebres. Esa misma noche comenzaron las entrevistas con los prohombres liberales para formar gobierno, esto es, con Venancio González, Martínez Campos, Jovellar, Beránger, Gamazo, Moret, Camacho y Vega de Armijo.

El nuevo gobierno: A las seis de la tarde del 27, llevaba Sagasta al Palacio de Oriente el nuevo gobierno ${ }^{35}$ : Gobernación, V. González; Estado, Moret; Gracia y Justicia, Alonso Martínez; Fomento, Montero Ríos; Hacienda, Camacho; Ultramar, Gamazo; Guerra, Jovellar, y Marina, Beránger. Esta formación fue aceptada por la Reina tras breve conferencia, y a las nueve de la noche, prestaron juramento los ministros. El Ministerio venía a representar la conciliación de liberales y demócratas y con ese carácter fue recibido por El Imparcial ${ }^{36}$; del mismo modo lo vio La Época, que por esa razón, y recordando lo que significaba la llamada Ley de Garantías, que ya hemos detallado, y que exigía la reforma constitucional, entiende que por peligroso no pueden aplaudir este programa que se estableció en la fórmula del 4 de junio de 1884; previenen de que si en el período 1881-1883 del gobierno liberal, el alma fue Alonso Martínez, que representaba a los moderados, al centro, en esta nueva época liberal el alma pasaba a ser Montero Ríos, representante de la fracción demócrata, del ala izquierdista el partido. Con lo que no contaba este diario ${ }^{37}$ era con que entre ambas fechas se había producido un acontecimiento decisivo, esto es, la muerte del Rey y el acuerdo entre los monárquicos,

${ }^{33}$ El Imparcial, 27 de noviembre, pág. 3, “Informes políticos».

${ }^{34}$ Por una alteración producida en la costumbre establecida para llamar a los jefes de partido en los momentos de crisis, el secretario de Sagasta no pudo distinguir la llamada del Palacio, que se produjo mediante un telegrama, que se perdió entre otros muchos. En todas las crisis aquéllos eran llamados a Palacio por medio del Mayordomo Mayor o del Intendente, y si la Corte estaba fuera, cumplian esta función los Caballerizos. En este caso, como decimos, llegó mediante un telegrama que llevó un ordenanza de Telégrafos. Esta fue la razón de que Sagasta no se enterara hasta que, probablemente, fue a despachar ia correspondencia corriente.

35 Ortega y Rubio, J., en su Historia de la Regencia de M. C Cristina Habsburgo-Lorena, sitúa equivocadamente la presentación del gobierno en el dia anterior, el 26 por la mañana, cuando todavia no se había producido la conversación entre Cánovas y la Regente, pág. 200, M. 1905.

${ }^{36}$ El Imparcial, 28 de noviembre, «El nuevo Ministerio".

${ }^{37}$ La Época, Idem, «El programa liberal». 
que haría que el enfoque político del partido liberal cambiara de objetivo. Sin embargo, atendiendo a esta nueva situación, el órgano conservador se adelante a advertir que ya aquel programa no tiene sentido, a la par que recuerda la falta de unión con López Domínguez, pronosticando por ello una guerra feroz entre los que siguen llamando fusionistas y la izquierda. Como último recurso para hacer desistir a los liberales de su hipotética aficción a aquel programa, sitúan a Sagasta en la disyuntiva de atender a sus deberes como hombre de Estado, al que se confió el porvenir de la Patria en tan delicada situación, o, faltando a éstos, atender el deber menor de cumplir un programa previamente pactado con sus seguidores. Azcárate, el 26 de junio en el Congreso, denunció esta evolución del partido liberal, en concreto de Sagasta, que tras las luchas sostenidas para defender un concepto más moderno de monarquía, la parlamentaria, acabó aceptando toda la idea doctrinaria de Cánovas, representada fundamentalmente en la soberanía compartida por las Cortes y la Corona, no sólo para la aprobación de las leyes ordinarias, sino que sometía a la sanción de la Corona la propia Constitución. Moret, queriendo salvar los ideales de su partido, dice que la unión monárquica la creyeron indispensable en el momento de morir el Rey, pero que luego "cada uno reivindicó los ideales de su partido y marcha por su camino"; pero al diferenciar los conceptos de soberanía popular y soberanía nacional, corrige la postura individualista tradicional del liberalismo, y se quiere acercar, o quiere explicar el acercamiento a Cánovas y su doctrinarismo, a través de la explicación organicista que de la sociedad hacían los krausistas y que luego dio frutos políticos, con el partido reformista de Melquíades Alvarez en 1914. Es decir, hizo una mezcla ad hoc mediante la que pretendía estar con Cánovas en los conceptos fundamentales, pero manteniendo a la vez, al menos de cara a la opinión y a los críticos, unas ideas propias, para lo que se apuntaba, adaptándolas a la necesidad del momento, a las nuevas ideas organicistas liberales que corregian el liberalismo tradicional ${ }^{38}$.

\section{EL COMIENZO DE LA REGENCIA}

Tras la formación del nuevo gobierno y tras producirse la jura del Ministerio el 27 por la noche, actuando como Notario Mayor del Reino el

${ }^{38}$ DSC, leg. 1886, t. Il, discurso de MORET el 1 de julio de 1886. Idem, para el discurso de AzCARATE de 26 de junio. Sobre los frutos políticos de esta idea organicista liberal vid. SUÁREZ Cortina, M., El reformismo en España. Madrid, Siglo XXI, 1986. También, LaRio GonzÁleZ, M. ${ }^{a}$ A., "La crisis ideológica de la Restauración: El "Nuevo Liberalismo" en el diario independiente El Sol (1917-1923)", resumen de esta Memoria de Licenciatura publicado en el Bulletin d" histoire contemporaine de l'Espagne. Universidad de Pau, diciembre de 1985 
ministro de Gracia y Justicia saliente, en este caso Francisco Silvela (el proceso normal es que al nuevo Presidente del Consejo le tome el juramento el ministro de Gracia y Justicia del gobierno anterior, tras lo cual se retira y pasa a tomar juramento a los demás ministros el recién nombrado Presidente del Gobierno), se procedió a tomar el juramento a la Regente, tal y como establece el artículo 69 de la Constitución ${ }^{39}$ para el caso de que las Cortes no estuvieran reunidas y no se convocaran inmediatamente. En este caso, además del gobierno, se mantuvo como testigo el propio Silvela, por expreso deseo de la Reina. Este juramento se produjo tras la lectura por Sagasta del citado artículo de la Constitución, "hincada de rodillas ante un crucifijo, y puesta la mano sobre el libro de los Santos Evengelios, hizo por sí misma el siguiente juramento: "Juro por dios y por los Santos Evangelios ser fiel al heredero de la Corona constituido en la menor edad, y guardar la Constitución y las leyes; y prometo reiterar este juramento ante las Cortes tan luego como se hallen congregados. Así Dios me ayude y sea en mi defensa, y si no, me lo demande" " ${ }^{40}$. Ante las Cortes juró el 30 de diciembre, en la sesión regia que se produjo al efecto en el Palacio del Congreso entre las catorce y quince treinta horas.

Vemos como no se especifica quien sería el heredero a la Corona, a pesar de que Alfonso XII y M. ${ }^{a}$ Cristina tenían ya dos hijas, habiendo nacido la mayor, $M .^{a}$ de las Mercedes, el 11 de septiembre de 1880 , justo diecinueve días después de ver la luz un Real Decreto, el 23 de agosto bajo el gobierno Cánovas, que derogaba el de 26 de mayo de 1850 , por el que quedaba indisolublemente unido el título de Príncipe de Asturias al de heredero del trono. Cánovas restringió el goce de este título desde el nacimiento a los varones que fueran inmediatos herederos; las Infantas y otros hijos del monarca sólo lo obtendrían por expreso deseo del Rey y en uso de sus prerrogativas. De este modo la primogénita de Alfonso XII no ostentó el título de referencia, a pesar de ser la reconocida heredera al trono, hasta el 11 de marzo de 1881, bajo el gobierno Sagasta, que discrepó abiertamente del concepto histórico y jurídico expuesto por el propio Cánovas como prólogo al citado real decreto. De igual modo, al morir el monarca, quedó en suspenso cualquier decisión sobre el futuro Rey hasta

39 “El Regente prestará ante las Cortes el juramento de ser fiel al Rey menor y de guardar la Constitución y las leyes. Si las Cortes no estuvieren reunidas, el Regente las convocará inmediatamente, y entre tanto prestará el mismo juramento ante el Consejo de Ministros, prometiendo reiterarle ante las Cortes tan luego como se hallen congregadas."

${ }^{40}$ La Gaceta 28 de noviembre de 1885. DSC, leg. 1885-86, 29 de noviembre. Vid. también El Imparcial, 28 de noviembre, "La jura"; y el 29, "El juramento de la Regente". 
que se produjo el nacimiento del hijo que estaba esperando la Regente cuando se quedó viuda. Sucedió, pues, que el trono estuvo vacante desde el 25 de noviembre hasta el 17 de mayo, ya que había Regente pero no había Rey reconocido, puesto que la primogénita y heredera nunca fue declarada Reina.

En el Parlamento, Muro López puso en duda la legalidad de esta situación ${ }^{41}$, mientras Castelar criticaba el modo de nombrar Regente, pues consideraba que eran las Cortes las encargadas de llevarlo a cabo; poniendo como ejemplo a la Inglaterra de hacía un siglo, cuando Pitt y el Príncipe de Gales llevaron al Parlamento la cuestión de la Regencia, pues mientras éste creía que le correspondia por heredad, Pitt decía que por elección, y ésta fue definitivamente la declaración que hizo el Parlamento, reforzando su prestigio, "desde entonces data la impersonalidad de la monarquía británica” ${ }^{42}$. Cánovas salió al paso de este argumento concluyendo que la Regente juró por serlo, no para serlo; es decir que lo es por derecho, no por elección, que su poder, diriamos nosotros, su legalidad, está por encima del poder y la legalidad que pueda otorgar la representación nacional. Efectivamente, M. ${ }^{a}$ Cristina tomó primero juramento a los nuevos ministros, como Regente, y luego prestó ella misma el juramento previsto por la Constitución. Entiende Cánovas que, precisamente, ese acto de nombrar gobierno era lo que más claro podía dejar ante todos, la plenitud de las facultades constitucionales de la Regente, que estaba usando de las supremas prerrogativas reservadas a la Corona y al que la personifica; todo ello, recordemos, antes de prestar cualquier juramento, ante el gobierno o las Cortes, sino por derecho intrínseco como representante del poder de la Corona.

Esta prisa por hacer entrar en funcionamiento la nueva legalidad, se debía a las reconocidas dificultades de doctrina y las posibles controversias en la interpretación que podía ocasionar la nueva situación, dado que, como indicaba Castelar, había un artículo en la Constitución que decía que "para que el pariente más próximo ejerza la Regencia necesita ser español..." (art. 68), siendo que la Regente era austríaca. Sin embargo, bien es cierto que el término de «pariente más próximo" se refería en el artículo anterior, al caso en que el Regente no fuera el padre o la madre del Rey menor de edad, con lo que parecía claro que por encima de cualquier otra consideración, la calidad de padre o madre primaba. Ayu-

\footnotetext{
${ }^{4}$ DSC, leg. 1885-86 cit. (tomo único), discurso de Muro López de 2 de enero de 1886 Alegaba el silencio de la Constitución acerca de los hijos póstumos.

${ }_{42}$ DSC, leg. 1886, t. Il, discurso de CASTELAR de 2 de julio de 1886 , y contestación de Cánovas, el día 3.
} 
daba a la confusión, no obstante, el hecho de que no se supiera quien era el heredero. No faltaron discrepantes, en suma, pero a ellos les replicó Cánovas con el hecho consumado. Todos parecian estar de acuerdo, sin embargo, en que «la situación de una minoria, si reúne todas las virtudes que son propias de la institución, no reúne todas las condiciones del momento para presentarse con aquel vigor, con aquella energía, con aquella acción que son y deben ser propias del poder moderador del Estado" " ${ }^{3}$. Lo cual vendría a justificar el intento de garantizarle al trono el concurso de los elementos básicos de la vida política, es decir, los dos grandes partidos que se habían formado en la época de Alfonso XII.

\section{LA CRISIS EN EL PARLAMENTO. EL PAPEL DEL MONARCA}

En esta crisis, la solución ya estaba dada antes de tener lugar el planteamiento oficial de la misma. Ya hemos visto cómo a instancias de Martínez Campos, Sagasta se entrevistó con la Reina el día anterior a la muerte del Rey, y antes de que se produjera el encuentro definitivo con Cánovas para llegar al acuerdo. En aquella entrevista el líder liberal aseguró a la futura Regente la defensa de la legalidad constitucional con todos los medios, respaldando el consejo del general de que se reclamara el concurso del partido liberal para la defensa de la monarquia; previamente había llegado, según vimos, a un acuerdo con los prohombres liberales en este sentido, de acuerdo probablemene con Martínez Campos para llevar a cabo esta estrategia política; tras la entrevista con la Reina, los ex-ministros liberales ratificaron su acuerdo, mientras Martínez Ocampo se entrevistaba con Cánovas con el fin de conseguir una necesaria armonía entre los líderes políticos, de cara a futuros acontecimientos. Fue el propio general quien comunicó a Cánovas el acuerdo de los liberales, y quien medió e impulsó el acuerdo, y consecuentemente abrió el camino a la solución de la crisis ${ }^{44}$.

Sin duda Martínez Campos actuó con rapidez y eficacia ante la inminencia de los sucesos, y al provocar la entrevista de Sagasta con la Reina, ponía a Cánovas y a los conservadores en posición de necesaria avenencia a la que éstos, de todas formas, parecían bien dispuestos en esta coyuntura. Si por una parte la crisis existía independientemente de la muerte del Rey, este acontecimiento y la posición ganada por los liberales el día 24, y por el propio Martínez Campos como el mejor aglutinante de

${ }^{43}$ DSS, leg. 1886, t. I, discurso de ROMERo GIRón.

" Vid. el apartado "la muerte del Rey decide la crisis. La inteligencia monárquica». 
las fuerzas monárquicas, indicaba cuál iba a ser el camino de su solución. No se puede decir, desde luego, que las crisis de 1879, a raíz de las cuales el citado general abandonó el partido conservador y se integró en las filas del liberal, no hayan tenido trascendencia para los futuros acontecimientos políticos, tanto para la llegada de los liberales al poder en 1881, como para este segundo período de gobierno de los mismos. La presencia de Martínez Campos en el partido liberal desde 1880 fue trascendental, tanto para la fluidez en la alternancia en el poder de liberales y conservadores, como, incluso, para coartar, por el compromiso que significaba, las posibles tendencias radicales que hubieran podido cuajar en el partido liberal, tras su unión con los demócratas y en el contexto del gobierno Cánovas-Pidal, según vimos.

En este contexto, de previos acuerdos y el sentimiento de fuerza del partido liberal, hay que entender que Sagasta asegurara en el Congreso que la Regente llamó a sus consejos a los liberales por decisión propia "por espontánea voluntad", a la par que niega la existencia de un pacto por el cual él estuviera en el poder a cambio de transigir en sus principios ${ }^{45}$

En el mismo sentido, es decir, poniendo en la voluntad de la Reina antes de producirse la crisis, la intención del cambio político, se expresa el citado artículo de El Mercantil Valenciano (nota 28) que aseguró que el Duque de Montpensier llegó de París para convencer al monarca de la necesaria salida de Cánovas del gobierno, y para decir después que ésta se produciría antes del mismo mes de noviembre. Apunta al mismo tiempo que la Reina Madre, Isabel II, también apoyaba la solución liberal, y lo que era más importante, la propia Reina $M .{ }^{a}$ Cristina, que habría juzgado de imprevisión los sucesos de la Legación alemana del 4 de septiembre, con lo que "comenzó a inclinarse marcadamente a los liberales", decidiéndose cuando, según el mismo diario, a principios de noviembre la plana mayor de este partido se reunió para «adoptar una línea de conducta ante la contingencia del fallecimiento del Rey", que no fue otra sino defender a todo trance la solución constitucional de doña M. ${ }^{a}$ Cristina. Por último, el Rey también habría llegado a creer hasta tal punto en la necesidad del cambio, que el propio Cánovas estaba ya buscando una salida airosa a la situación ${ }^{46}$.

Sagasta en el Congreso negó en diversas ocasiones la visión pactista de esta crisis, y llegó a indicar las divisiones del partido conservador como

${ }^{45}$ DSS, leg. y t. cit., discurso-resumen de SAGASTA, el 31 de mayo de 1886.

"66 Vid. el apartado "El planteamiento de la crisis". 
la causa que la hacían imprescindible, surgiendo no tanto del pacto como de una necesidad anterior al mismo que obligaba al cambio de gobierno; esta interpretación fue avalada por el propio Romero Robledo, el inevitable ministro de Gobernación conservador, al explicar su salida de este Ministerio en julio de 1885; Francisco Silvela completó esta explicación, rectificando al anterior y escenificando así en plenas Cortes la efectiva división de los conservadores a que aludía Sagasta ${ }^{47}$.

El mismo Azcárate entiende que a Cánovas no le quedaba otra alternativa de dejar paso a los liberales, porque según sus palabras, "la revolución, que tenía ya el dies cedit, habría tenido el dies venit’ ${ }^{48}$, aludiendo a la alta tensión política que se vivía desde 1884; considerada su conducta como desinteresada desde el punto de vista del partido, pero hábil; comparando esta llegada de los liberales con la llamada de Martínez de la Rosa y la promulgación del Estatuto Real tras la muerte de Fernando VII. Efectivamente en aquellos momentos era necesario abrir, aunque fuera levemente, pero sin posibilidades de retorno, el camino de las conquistas liberales; y tras la muerte de Alfonso XII se trataba de asegurar, aunque también humildemente pero cerrando el camino de retroceso, las teorías democráticas que había introducido la Constitución de 1869 y que la Restauración pretendía interpretar y modelar adecuadamente; lo cual sólo sería posible si las hacía vivir en su seno.

Hemos de entender precisamente el pacto entre los partidos, como el acuerdo tomado de limitar los avances que rompieran la armonía política, haciendo prevalecer lo que se consideraba, o llamaban el interés de la monarquía, por encima de cualquier otro, interpretado éste en aquellos momentos de lucha, como la paz entre los partidos y la convivencia pacífica, que implicaba que todas las reformas políticas pudieran ser aceptadas por ambos, con el objeto de no producir rompimientos ni situaciones difíciles a la regia prerrogativa que se encontraba ahora en época de minoridad y en manos de una mujer. Así el pacto sirvió en esta crisis para que Cánovas aceptara sin lucha la inevitable llegada de los liberales, y para que ésta tuviera un carácter distinto al esperado o temido, pues refrenó las tendencias reformadoras, según denuncia el senador Rojo Arias, destacando las palabras del conservador Marqués de Molíns cuando decía que «estamos la minoría conservadora y el gobierno en una tregua; no hay alianza, no hay convenido de ninguna especie; hay una tregua, y ROBLEDO.

${ }^{47}$ DSC, leg. $1885-86$ cit., discurso de Sagasta de 4 de enero de 1886. Idem, de Romero

${ }^{48}$ DSC, leg. 1886, t. I, discurso de Azcáate de 22 de junio de 1886. 
durante ella no podemos combatir ni en pro ni en contra del gobierno", pero, destaca Rojo, como el mismo Marqués de Molíns añadió que cuando el gobierno trajera los proyectos que contradicen sus principios entonces se opondrían, por lo que, afirma que es ilícito que sabiendo esto el partido liberal aceptara el pacto: "el partido liberal viene con un programa que sabe no ha de cumplir: tenía que haber traído los proyectos al abrir las Cortes, y si creía que las circunstancias eran peligrosas y no podía gobernar con sus principios, estaba obligado a irse de ese banco y llamar a los demás partidos que estuvieran en condiciones de sostener una situación de fuerza» ${ }^{49}$. En este contexto hay que entender las limitaciones del nuevo gobierno liberal, gráficamente dibujado por Romero Robledo: «iComo si los pactos de este género constituyesen cosas taxativamente tratadas y elevadas a documento público! icomo si no hubiera en la vida civil cuasicontratos y acciones que obliguen a aquellos en cuyo favor resultan a tener cierta correspondencia con sus adversarios!» 50 .

Efectivamente, tras la unión de los monárquicos, y a pesar de lo que temiera La Época, en el concepto liberal expresado en estas Cortes, tanto por Sagasta como por los recientemente incorporados Maura (a quien Azcárate dijo premonitoriamente que se había equivocado de partido) y Canalejas, triunfó «la monarquia del señor Marqués de la Vega de Armijo (con sus atributos esenciales) sobre la monarquía del señor Martos» "51; en el sentido de que se acepta que el monarca hubiera de sancionar, además de las leyes ordinarias, la propia Constitución, con lo que se asumía el concepto doctrinario de Cánovas de que la monarquía está por encima, es anterior a la Carta Magna y por tanto es irrevocable e irrenunciable. Aunque Sagasta para evitar esta tajante afirmación juega con los conceptos e intenta distinguir entre soberanía constituyente y soberanía constituida; por la primera se fundaría la monarquía y por la segunda se pasa a ejercer esa soberanía, papel que corresponde al Rey con las Cortes; y sin sacarnos de más apuros teóricos viene a confirmar su total aceptación de hecho de la situación establecida, ya que no llega a aclarar si una vez fundada la monarquía podía ser revocada o no, dando a entender con su aceptación de la soberania compartida que no, ya que es impensable que el Rey sancionara su propia destitución ${ }^{52}$. Moret, según

\footnotetext{
${ }^{49}$ DSS, leg. 1886, t. I, discurso del Marqués de Molins de 26 de mayo; de Rojo Arias, el 27 ,

5o DSC, ldem discurso de Romero Robledo de 25 de junio.

${ }^{51}$ DSC, Idem, t. Il, discurso de AzCÁRATE de 26 de junio. Vid. los discursos en el mismo día de Canalejas, y en 23 del mismo mes de Maura.

52 DSC, Idem, discurso de SAGasta, en el mismo día 26. Salmerón se extenderá sobre este tema en su discurso del 3 de julio.
} cit. 
adelantamos al final del apartado «el planteamiento de la crisis», para salvar al menos aparentemente los ideales de su partido, se atiene al concepto krausista de sociedad, explicando la soberanía nacional como algo distinto a la soberanía del número, puesto que los diferentes organismos que componen aquélla requieren diferentes modos de representación ${ }^{53}$; con lo que estaría limitado el posible temor al sufragio universal, de esta forma corregido por una representación corporativa, insiste en el peso de la historia, los actos del pasado, dice, se traducen en instituciones que han de estar presentes en la organización política de cada momento; de este modo habría que combinar siempre lo actual, esto es, la voluntad popular expresada en votos, con lo pasado, esto es, las instituciones. Con ello está asumiendo, ni más ni menos, que la teoría de la Constitución interna de Cánovas, término acuñado por el político conservador, según él mismo recuerda, a la salida de Amadeo y la proclamación de la Primera República, cuando dice que "existe la (Constitución) interior, inherente a la Nación española, incorporada en la historia y en su propia vida, y este algo son las costumbres, que constituyen una especie de Constitución interna"; con ello venía a expresar que las Cortes y la monarquía son la base de toda legalidad, que sin ellos no existe ${ }^{54}$.

Nunca hasta ahora se había logrado tal confluencia de pensamiento entre los partidos políticos que se disputaban el poder en la Restauración; y todo ello para justificar su nueva postura de aceptación total de lo establecido bajo este régimen, definida sobre todo por la asunción que hacen los liberales de que los votos, las Cortes por sí solas no tenían poder para tocar los fundamentos de la monarquía como representante máximo, junto con ellas mismas, de la soberanía nacional; de hecho Moret dijo públicamente en el discurso citado que habia abandonado el principio de soberanía popular que sostenía la izquierda, al mismo tiempo que Cánovas reclamaba como propia la teoría expuesta por el diputado liberal.

La explicación oficial de la crisis que hace Cánovas, si por una parte quiere limitar su propia acción, reconociendo en buena práctica constitucional que el poder se lo otorgó al partido liberal la Regente en uso de sus prerrogativas, no deja de destacar su firme apoyo y su explícito con-

${ }^{53}$ Sobre la teoría liberal krausista se puden ver: DiAz, Elías, La filosofia social del krausismo español. Madrid, Cuadernos para el diálogo, 1973; GIL Cremades, J. J., Krausistas y liberales. Madrid, Seminarios y Ediciones, 1973. Idem, El reformismo español. Krausismo, escuela histórica, neotomismo. Barcelona, Ariel, 1969. Gómez MOLLEDA, D., Los reformadores de la España contemporánea. Madrid, CSIC, 1981. López MoRILLAS, J., El krausismo español. México, FCE, 1980. Posada, A., Breve historia del krausismo español. Universidad de Oviedo, 1981.

${ }^{54}$ DSC, Idem, discurso de Moret del 1 de julio. Discurso de Canovas del 3 del mismo mes. 
sejo a la Reina, para que esto sucediera. Afirma que él mismo influyó para que $M .{ }^{a}$ Cristina no le dijera una palabra sobre continuar en el gobierno, reconociendo que «hubiera sido poco honroso... en el caso de que sin solicitarlo (la formación de un nuevo Gabinete), se me hubiera hecho esta indicación " ${ }^{55}$; en cualquier caso, 10 cierto es que Cánovas se preocupó de no dar lugar a situaciones confusas, pues que con precipitación que la propia Reina viuda no aceptó con gusto, se prestó a hacer dimisión de su gobierno, según hemos podido ver; lo cual demuestra, cuando menos, la certeza que tenía de que no podía continuar el partido conservador en el poder con la tranquilidad necesaria, ni siquiera con la autoridad que le podía otorgar la plena confianza regia. Esto no desmiente que Cánovas se haya apartado del poder por propia iniciativa, si entendemos como tal que la Corona no le impulsó abiertamente a que lo hiciera (tampoco se le dio tiempo para ello); sin embargo teniendo en cuenta el tipo de relación establecido entre el Rey y sus ministros, en la que la necesidad de la total confianza regia da importancia a cualquier signo que haga dudar a los partidos o a la opinión pública sobre la existencia de aquélla, la entrevista de Sagasta con la Regente dieciséis horas antes de la muerte del Rey ${ }^{56}$, fue un hecho bien significativo de hacia donde se dirigía el pensamiento regio, no pudiendo ocultársele a nadie su importancia. Éste fue el paso previo del acuerdo monárquico: la Reina otorgaba beligerancia a Sagasta y le ponía a la misma altura de Cánovas de cara a la lucha por el poder; después de esto el acuerdo entre los partidos fue posible y la solución de la crisis evidente, avalada una vez más por el General Martínez Campos, quien habia aconsejado a M. ${ }^{\text {a }}$ Cristina que reclamara el concurso del partido liberal, para lo cual se llevó a cabo la entrevista, según ya vimos.

La misma existencia del acuerdo, sirvió a Cánovas para salir airoso del poder "pues que yo me levantaba a proponer la concordia y a pedir la tregua, no había otra manera de hacer creer en mi sinceridad sino apartarme yo mismo del poder... para que ese programa (de paz y concordia) se aceptara era menester que yo diera el ejemplo. iAh! ¿Qué querían? ¿Que yo por ambición, por vanidad, por despecho, por intereses particulares y mezquinos de partido, hubiera mantenido el estado de cosas, aquel estado de lucha tal como existía entre los partidos, que aquella lucha se hubiera ensangrentado...? ${ }^{57}$. Los liberales, sin embargo, no estaban dispuestos a que se les restaran méritos en su ascensión al poder,

Discurso de Canovas cit.

55 Vid. el apartado "La muerte del Rey...".

57 Discurso de Canovas cit. 
asegurando que la Reina actuó con "completo conocimiento de causa llamando al partido (liberal)", mientras los conservadores se amparaban, en último extremo, en la corresponsabilidad de los jefes de partido al aceptar uno salir y el otro entrar en el poder, ateniéndose al crítico momento político que se estaba viviendo y la necesaria tregua entre los partidos. Ambos intentando defender la autonomía, la dignidad y el propio poder de sus partidos respectivos; y aunque los dos jugaban con una parte de la verdad, la mayor parte de ésta le correspondía a los liberales, que se atenían a la evolución de la crisis hasta que se produjo el momento decisivo de la muerte del Rey, que tuvo como consecuencia la solución inmediata de la misma en el sentido que se podía preveer, pero, y esto fue crucial, corregido por la establecida unión monárquica frente a los enemigos externos y las posibles debilidades internas que habría de dar el definitivo carácter al sistema político de la Restauración ${ }^{58}$.

\section{CONCLUSIÓN}

Hemos visto, en definitiva, cómo en el ambiente surgido tras la crisis de 1884 , emerge una creciente crítica a las costumbres políticas establecidas hasta aqui dado al enfrentamiento de los partidos por la lucha por el poder, y posiblemente a la creencia por parte de los liberales de que salían perdiendo en el reparto del mismo, y que quizá sería conveniente procurar ciertas reformas, 0 , en su caso, utilizar estos defectos como potente arma de lucha, casi de constante chantaje para afianzarse en una parcela segura del poder. La existencia de la amenaza republicana y carlista presta mayor eficacia a sus críticas y denuncias. Pero no sólo a la oposición liberal llegaban estas críticas; el propio embajador en Londres hablaba de una "grave empresa de regeneración y reconstrucción" que tendría que iniciar el Rey, esperanzado por su feliz intervención en el asunto de las Carolinas ${ }^{59}$.

Pues bien, todo este clima político cambió con la muerte de Alfonso XII y la unión de los monárquicos vino a significar en la relación estable-

${ }^{58}$ DSS, leg. 1886, t. I, discurso de Rivera (de la comisión para la contestación al mensaje de la Corona). Este orador dio lugar a alguna sonrisa burlona, caso del señor Botella, al equivocarse de nombre de partido, pues al querer referirse al Liberal-demócrata, dijo -muy a propósito con el ambiente de crítica al Partido Liberal por aceptar el pacto que implicaba un freno a sus avances democráticos - Partido Liberal Conservador, dejando en el ánimo de los que le escuchaban, seguramente, la sensación de que el error no era de bulto: 26 de mayo. Vid. para el caso conservador el discurso de Manuel SILVELA del 28.

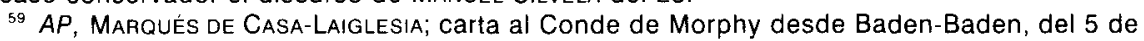
octubre de 1885. 
cida entre los poderes (recordemos que la Corona había revitalizado su poder en el contexto de la lucha entre los partidos) un reforzamiento de la institución del Gobierno (que no existía en la Constitución de 1876, pero sí en la práctica, unida inextricablemente al afianzamiento de la figura del Presidente del Consejo de Ministros, que va creciendo frente a los poderes de la Corona; en España se menciona esta figura por primera vez en el Estatuto Real de 1834, sin embargo no aparece regulado, junto con el Gobierno hasta la Constitución de la Segunda República, de 9 de diciembre de 1931; en Inglaterra, por ejemplo, no se reconoce formalmente hasta 1937 la figura del Presidente del Consejo, mientras en Francia se crea el Consejo de Ministros con su Presidente mediante ordenanzas de junio y julio de 1815; Alemania se adelantó, pues la República de Weimar organizada constitucionalmente el 11 de agosto de 1918, reguló el gobierno y su Presidente, aportando todo un marco jurídico de actuación; previamente, en la Constitución de 1871, ya aparecía recogida la figura del Canciller ${ }^{60}$. Este reforzamiento se amparaba en el control que los partidos ejercían sobre los cambios políticos, y por tanto lo era tanto frente a la Corona como frente al Parlamento cuya falta de representatividad facilitada esta situación. Cánovas y Sagasta al establecer unas normas de comportamiento político, cuyo origen se encuentra en esta unión monárquica, y que tenía como objetivo el autocontrol del proceso político $\sin$ necesidad de acudir a instancias superiores (en la misma línea en que se expresaba Francisco Silvela el 4 de enero de 1886, citado en la nota 9), están limitando el poder de la Corona, justificado en este caso a sus ojos y a los de la opinión por la debilidad que se suponía representaba una Regencia, y sobre todo una Regencia femenina. Fuera por lo que fuese la situación quedaba definida de la siguiente manera: unas Cortes no representativas, controladas por las mayorias que cada partido gobernante conseguía ineludiblemente en las elecciones, dirigidas desde el Ministerio de la Gobernación al que se sumaba un fuerte control local de las respectivas familias políticas; por el otro lado, en el esquema del poder, una Corona a la que pactadamente los partidos políticos decidían limitar sus prerrogativas en la práctica, al entender que no debía existir lucha política a la hora de abandonar el poder, sino que, por el contrario, entre las funciones de los partidos estaba la de una alta imparcialidad para apreciar sus

${ }^{60}$ Sobre el gobierno y su Presidente se pueden consultar entre otros: BAR, A., El Presidente del gobierno en España. Encuadre constitucional y práctica política. Madrid, Civitas, 1983. REVENGA SÁNCHEZ, M., La formación del gobierno en la Constitución española de 1978 (con una introducción y un primer capítulo en los que se remite a los antecedentes históricos). Madrid, CEC, 1988. Escudero, J. A., Los orígenes del Consejo de Ministros en España: La Junta Suprema de Estado. Madrid, Ed. Nacional, 1979. 
propias fuerzas y la oportunidad de la gobernación; no se podía reducir sus tareas a la de conservar el poder o conquistarlo cuando no se tiene. Decididamente aseguraba Silvela en el discurso citado, frente a Romero Robledo, que no se debía abandonar a los altos poderes del Estado la tarea de regular la hora en que cada partido debía abandonar el poder. Evidentemente el acuerdo entre los partidos era el método más eficaz de controlar las prerrogativas regias que según la Constitución ocupa una amplia parcela de poder; el gobierno y los partidos que no tenían asignada ninguna, supusieron que en ella debian establecer su campamento desde donde procuraban manejar los hilos que sujetaban a las Cortes y a la Corona. En la medida en que este control fuera eficaz, tendrian asegurado a su vez el control de la vida política, al menos de la vida institucional que ocupó una buena parte de sus preocupaciones. 